\title{
Quantification of sponge/coral interactions in a physically stressed reef community, NE Colombia
}

\author{
L. A. M. Aerts ${ }^{1,2, *}$ R. W. M. van Soest ${ }^{2, * *}$ \\ 'Instituto de Investigaciones Marinas Punta de Betin, Santa Marta, Colombia \\ ${ }^{2}$ Institute of Systematics and Population Biology, University of Amsterdam, PO Box 94766, 1090 GT Amsterdam, \\ The Netherlands
}

\begin{abstract}
Coral reef sponges are considered to be important space competitors. Competitive interactions between sponges and corals often result in overgrowth of the coral. It is assumed that sponges are even more successful in environments sub-optimal for corals. In order to test the hypothesis that coral overgrowth by reef sponges increases when corals are under stress, the frequency of sponge/ coral interactions was quantified along a gradient of physical stress. At 15 stations, encompassing 5 localities and 3 depths $(5,10$ and $20 \mathrm{~m}$ ) along the coast of Santa Marta (NE Colombia), the number and categories of interactions were scored in belt transects $\left(10 \times 1 \mathrm{~m}^{2}\right)$. Four categories of interactions were distınguished. Physical factors such as sedimentation and visibility were measured. 21 coral species and 95 sponge species were encountered in a total of 3866 sponge/coral interactions. Only $2.5 \%$ (96 interactions) consisted of overgrowth of corals by sponges. The frequency of such overgrowth depended on the presence of particular sponge species, which appeared to be more aggressive towards corals in localities with high coral cover, relatively low sedimentation and high visibility. Thus, we reject the hypothesis that coral overgrowth by sponges occurs more frequently in localities under physical stress. Overgrowth was related to the presence of aggressive sponge species, rather than to characteristics of the corals. It is concluded that reef sponges differ notably in their competitive abilities. By influencing the sponge community composition on the reef, the physical environment may indirectly determine the extent of overgrowth of corals by sponges.
\end{abstract}

KEY WORDS: Interactions Overgrowth Physical stress Sponges $\cdot$ Coral reef $\cdot$ Caribbean

\section{INTRODUCTION}

Space is a limiting resource for sessile organisms living on hard substrata (Dayton 1971). This is especially the case on coral reefs, which support a high diversity of benthic fauna and flora (Connell 1976. Jackson 1977). The ability of a benthic sessile species to gain and hold space depends on its competitive ability. Lang $(1971,1973)$ demonstrated the existence of an aggressive hierarchy among scleractinian corals. Since then, coral interspecific interactions have been

\footnotetext{
- Correspondence address: Institute of Systematics and Population Biology, University of Amsterdam, PO Box 94766, 1090 GT Amsterdam, The Netherlands.

-.E-mail: soest@bio.uva.nl
}

intensively studied in the field. It appears that the structure of coral/coral interactions is not completely hierarchical, because the outcome depends on numerous physical and biological factors (Bak et al. 1982, Bradbury \& Young 1983, Logan 1984). Mechanisms operative in competition differ between coral species (reviewed in Lang \& Chornesky 1990) and the competitive hierarchy of corals tends only to be transitive when the competing species employ similar competitive mechanisms. This transitive hierarchy breaks down when the competing species are able to develop other competitive structures, for example sweeper tentacles, making the outcome of the encounters dependent both on the character of the competing species and the environment (Chornesky 1989). Although the ranking of competitive abilities between species often lacks a simple linear hierarchy, ranking 
between the major taxonomic groups is basically hierarchical (Russ 1982)

In addition to interactions among themselves, corals frequently come into contact with sponges. In coral reef communities, sponges play an important role in competition for space (Suchanek et al. 1983). Because sponges lack special competitive organs such as mesenterial filaments and associated behaviour, they are thought to use their toxic substances in interaction with other benthic organisms to actively gain and maintain their positions on the substrata. Encounters between sponges and corals usually result in damage to the coral (Jackson \& Buss 1975, Suchanek et al. 1983, Sullivan et al. 1983), even in non contact situations (Porter \& Targett 1988). Some sponge species are able to occupy large reef areas at the expense of corals (Vicente 1978, Rützler \& Muzik 1993).

As nutrients and sedimentation increase on coral reefs, the effect of sponges on corals is becoming increasingly important. Nutrient enrichment may enhance benthic algal biomass and primary production in the water column. Increased primary production favors benthic filter-feeding organisms, which may out-compete corals (Pastorok \& Bilyard 1985). Concerning nutrient and sediment increase, sponges and corals can be seen as opposites, with sponge biomass increasing and coral biomass decreasing in reefs with organic pollution and high sediment load (Chalker et al. 1985, Rogers 1990, Wilkinson \& Cheshire 1990). Increasing sedimentation can alter biological processes on a reef, such as interactions between organisms (Rogers 1990). Competition in reef corals involves investment of energy (Rinkevich \& Loya 1985) and, because physical stress leads to a decline in biological functions of corals (e.g. the recovery from damage; Meesters \& Bak 1993), it seems likely that aggressive interactions between sponges and corals may increase and be more successful for sponges in physically stressed localities. The wide-spread overgrowth of corals in Japanese reefs by the sponge Terpios hoshinota is assumed to occur especially in pollution-stressed zones (Rützler \& Muzik 1993). However, studies on sponge/coral interactions investigated only the effect of individual sponge species and do not provide evidence as to whether a competitive hierarchy exists between sponges and corals at a community level. In our study we hypothesize that coral stress, induced by environmental conditions, is advantageous to sponges, which benefit on a community level by overgrowing living coral.

The reefs east of Santa Marta, NE Colombia, are particularly suitable for testing this hypothesis. These coastal reefs are not as well developed as those in other areas of the Caribbean (Von Prahl \& Erhardt 1985), due to a combination of seasonal upwelling and relatively high sediment load through terrigenous effluents. Within the area there is a roughly defined gradient, in terms of increasing coral cover, from the city of Santa Marta to the east. This is probably caused by a decrease of continental run-off from the SW to the NE (Zea 1994). Related to this gradient are an overall decrease of coral cover and an increase of sponge cover that have been observed over the past years, especially around the city (Werding \& Sanchez 1988, Zea 1994j. This phenomenon can be explained by an increase of sediment and nutrient loads through extensive deforestation (Zea \& Duque 1989) and increased garbage and raw sewage discharge (Escobar 1988, Cruz \& Ramirez 1990).

In this study, the most important sources of physical stress for corals along reefs were considered to be high sedimentation rates (Porter 1987, Rogers 1990) and low light conditions (Chalker et al. 1985). To test our hypothesis that coral overgrowth by sponges increases when corals are under stress, natural rates of encounter between sponges and corals were quantified along the existing gradient of physical stress.

\section{MATERIALS AND METHODS}

Study area. Fifteen stations, encompassing 5 localities along the coast of Santa Marta, NE Colombia (from west to east: Punta de Betin, El Morro, Granate, Chengue and Gairaca; see Fig. 1), and 3 depths $(5,10$ and $20 \mathrm{~m}$ ) were sampled for sponge/coral interactions and physical factors.

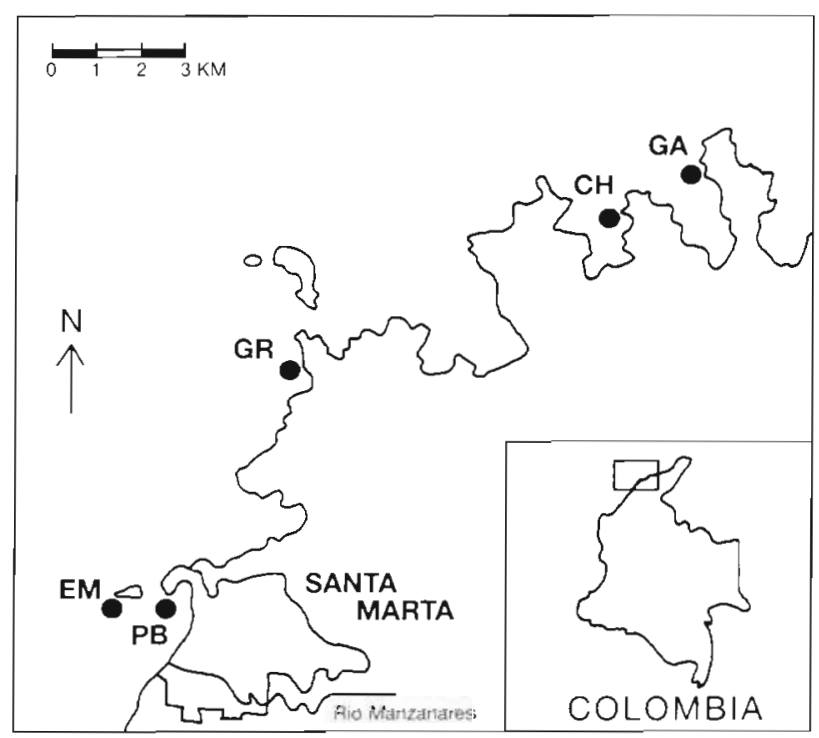

Fig. 1 Study area with sampling localities (Colombia). PB = Punta de Betin, $E M=E l$ Morro, $G R=$ Granate,$C H=$ Chengue and $\mathrm{GA}=$ Gairaca 
Physical environment. Sedimentation rate was measured using PVC sediment traps with a ratio between length and diameter of $5: 1$ (length: $30 \mathrm{~cm}$, diameter: $6 \mathrm{~cm}$; as in Larsson et al. 1986). The traps (1 per station) were left in situ for periods of 2 mo between February 1993 and February 1994, resulting in 6 samples per station. The sedimentation data set of this study was expanded by adding the data of $M$. Kielman (pers comm.), sampled in 1991 and 1992. The trap size and sampling method of these additional data were similar to those described above. Sedimentation was expressed in $\mathrm{g} \mathrm{m}^{-2} \mathrm{~d}^{-1}$, dry weight.

Visibility in the water column was measured at each locality using a $30 \mathrm{~cm}$ secchi disk. The measurements were carried out weekly, over a 1 yr period, at approximately the same hour and under similar weather conditions.

Differences in sedimentation rates between localities were analysed using the Wilcoxon signed ranks test (Sokal \& Rohlf 1981) taking depth and dates as blocks. For differences in depth the same test was used taking localities and dates as blocks. Differences in visibility between the localities were also analysed with the Wilcoxon signed ranks test, taking dates as blocks.
Non-transformed and log-transformed data of sedimentation and visibility showed non-normality (checked with Kolmogorov-Smirnov tests; Sokal \& Rohlf 1981).

Quantification of sponge/coral interactions. The quantification was carried out along belt transects. A $10 \mathrm{~m}$ line was attached to a randomly chosen point and stretched out parallel to the isobath of each depth $(5,10,20 \mathrm{~m})$. Ten consecutive quadrats of $1 \mathrm{~m}^{2}$ were laid adjacent to the line. This procedure was repeated 3 times, resulting in a sampling area of $30 \mathrm{~m}^{2}$ at each station. In total, $450 \mathrm{~m}^{2}$ were sampled for sponge/coral interactions. Because some coral species possess sweeper tentacles, which can reach a maximum distance of $5 \mathrm{~cm}$ (Richardson et al. 1979), and sponges are able to affect corals even in non contact situations (Porter \& Targett 1988), each sponge encountered within $5 \mathrm{~cm}$ from a coral was considered as a partner in an interaction. Four categories of interactions were defined (Fig. 2):

$A=$ overgrowth of living coral by sponges.

$\mathrm{B}=$ peripheral contact of sponge along and parallel to the living coral for more than $3 \mathrm{~cm}$. This category involves those encounters in which the sponge is obviously following the coral boundary.
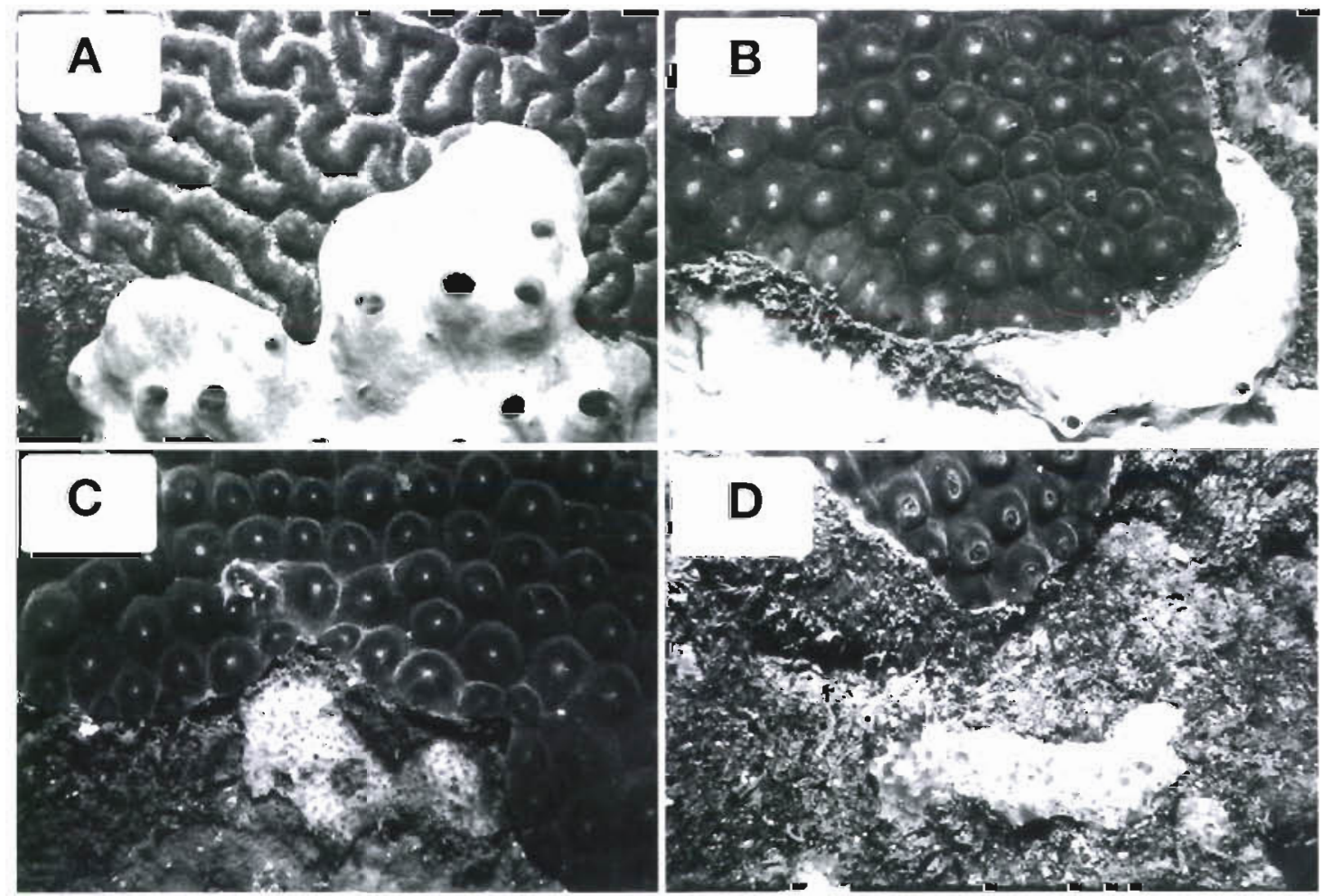

Fig. 2. Photographs of the 4 categories of interaction. (A) overgrowth of the coral Diploria strigosa by the sponge Desmapsamma anchorata; (B) peripheral contact of the sponge Rhaphidophlus venosus with the coral Montastrea cavernosa; (C) tissue contact of the sponge Niphates erecta with the coral M. cavernosa; (D) non contact interaction shown by the sponge Scopalina ruetzleri and the coral M. cavernosa 
$\mathrm{C}=$ tissue contact; a sponge is in contact with the edge of a living coral over a distance less than $3 \mathrm{~cm}$. This category involves those encounters in which contact seemed merely accidental.

$D=$ non contact; the sponge grows within $5 \mathrm{~cm}$ distance of the living coral boundary.

In each quadrat the total number of sponge individuals and coral colonies, the total coral perimeter for each species and the total cover (in \%) of sponges, corals and sand were noted. The interacting sponge and coral species were identified and the size of the interacting sponge (in $\mathrm{cm}^{2}$ ) was measured. In each interaction the affected coral area (in $\mathrm{cm}^{2}$; only for category $\mathrm{A}$ ), the extent of interaction (in $\mathrm{cm}$; for $\mathrm{B}$ and $\mathrm{C}$ ) and the distance between the sponge and coral (in $\mathrm{cm}_{i}$ only for $\mathrm{D}$ ) were recorded.

To test whether a relation existed between the frequency of a certain category of interaction and sponge and coral cover, a multiple regression was used. There was no relation between the 2 independent variables, sponge and coral cover (simple regression test). To normalise the data, the number of interactions and the sponge and coral cover were $\log$-transformed $(\log x)$. Every $10 \mathrm{~m}^{2}$ survey was used as a sample unit, resulting in 3 replicates at each station. Differences between regression slopes were tested with the GT2-method and Gabriel's approximate method (Sokal \& Rohlf 1981).

Percentages of overgrowth were calculated from the total number of interactions (= categories $A, B, C, D$ ) using every $30 \mathrm{~m}^{2}$ survey as a sample unit. These percentages were arcsin-transformed and tested on differences between depth and localities with a single classification ANOVA and the T-method. Bartlett's test was used to test the homogeneity of the sample variances (Sokal \& Rohlf 1981).

\section{RESULTS}

\section{Physical environment}

Sedimentation rates fluctuated greatly throughout the year and between years. Seasonal changes, such as the rainy and dry seasons, caused fluctuations of sedimentation rates within a year. Depending on the extent of rainfall, wind force and the prevailing wind direction, the sedimentation rate and visibility varied for each locality and depth within seasons. Due to these annual and seasonal fluctuations, analyses were carried out with dates as blocks. Sedimentation was significantly higher in the westernmost locality (PB) than in the other localities ( $p<0.01$; Fig. 3A). Between depths, the sedimentation was significantly higher at $5 \mathrm{~m}$ than at 10 and $20 \mathrm{~m}$ ( $\mathrm{p}<0.001$; Fig. 3B). The 'normal' sedimentation rate ranged from 4 to $247 \mathrm{~g} \mathrm{~m}^{-2}$

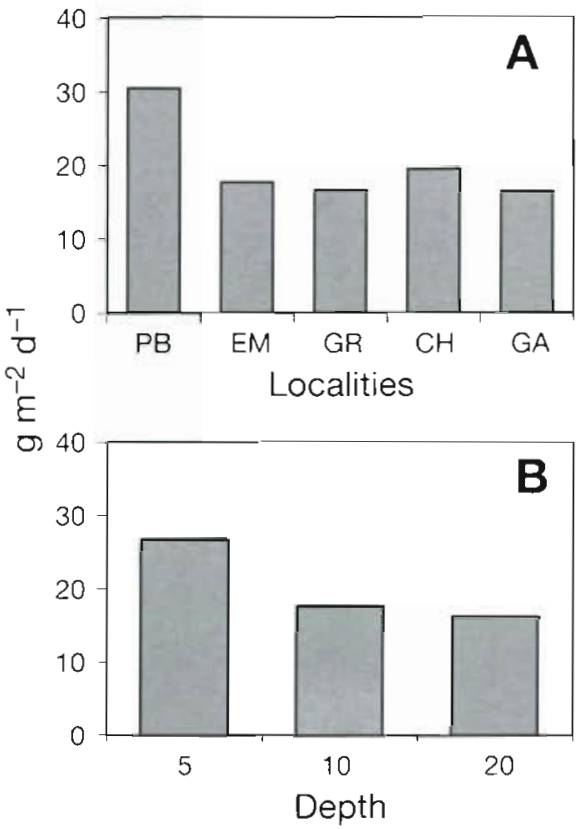

Fig. 3. Median of sedimentation rates in $\mathrm{g} \mathrm{m}^{-2} \mathrm{~d}^{-1}$ for (A) localities and (B) depth. Abbreviations of localities as in Fig. 1

$\mathrm{d}^{-1}$. In March 1993, due to the influences of a tropical storm, sedimentation rates ranged from 22 to $983 \mathrm{~g} \mathrm{~m}^{-2}$ $\mathrm{d}^{-1}$. The non-parametric median is used because of the few high sedimentation rates.

Visibility ranged from 4 to $22 \mathrm{~m}$. Two groups of localities could be distinguished: the group with lowest visibility consisted of $\mathrm{PB}$ and $\mathrm{EM}$ and the group with highest visibility consisted of $\mathrm{GR}, \mathrm{CH}$ and $\mathrm{GA}(\mathrm{p}<0.01$; Fig. 4).

\section{Quantification of sponge/coral interactions}

$$
\text { Interactions in general }
$$

There were 95 sponge species and 21 coral species engaged in sponge/coral interactions. A total of 3866 interactions was scored: $96(2.5 \%)$ overgrowths, 670

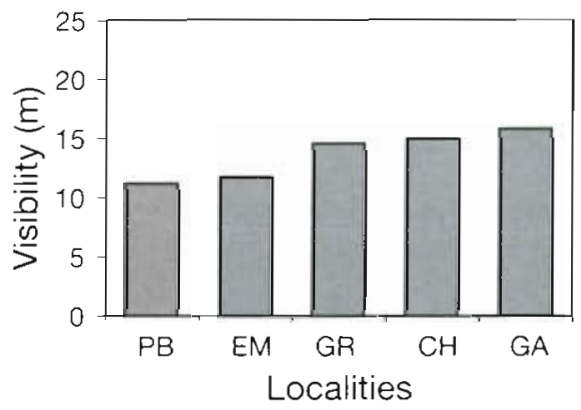

Fig. 4. Mean visibility in meters for each locality. Abbreviations of localities as in Fig. 1 
Table 1 Percentage occurrence of each interaction category for each sponge and coral species. A: overgrowth; B: peripheral contact; $\mathrm{C}$ : tissue contact; D: non contact. n: total number of interactions. Species with less than 5 interactions were omitted

\begin{tabular}{|c|c|c|c|c|c|c|c|c|c|c|c|}
\hline & $\mathrm{A}$ & $\mathrm{B}$ & $\mathrm{C}$ & $\mathrm{D}$ & $\mathrm{n}$ & & A & B & $\mathrm{C}$ & $\mathrm{D}$ & $\mathrm{n}$ \\
\hline Sponge species & & & & & & Mycale laevis & 0.5 & 61.5 & 27.5 & 10.4 & 182 \\
\hline Acanthella cubensis & & 9.1 & 9.1 & 81.8 & 11 & Mycale laxissima & & 20 & & 80 & 5 \\
\hline Acarnus nicolae & & 23.5 & 38.2 & 38.2 & 34 & Mycalesp. & & & 25 & 75 & 12 \\
\hline Agelas clathrodes & 6.1 & 27.3 & 33.3 & 33.3 & 33 & Myxillidae & & & 22.2 & 77.8 & 9 \\
\hline Agelas conifera & 8.3 & 50 & 16.7 & 25.0 & 12 & Neofibularia nolitangere & & 30 & 20 & 50 & 10 \\
\hline Agelas sp. 1 & & & 36.4 & 63.6 & 11 & Niphates digitalis & & & & 100 & 6 \\
\hline Agelas sp. 2 & & 40 & 30 & 30 & 10 & Niphates erecta & 2.5 & 18.2 & 31.1 & 48.1 & 318 \\
\hline Aka cachacrouensis & & 18.2 & 36.4 & 45.5 & 11 & Pleraplysilla sp. & & 3 & 51.5 & 45.5 & 33 \\
\hline Anthosigmella varians & 7 & 30.2 & 20.9 & 41.9 & 43 & Polymastia tenax & & 14.3 & 42.9 & 42.9 & 7 \\
\hline Aplysilla sp. & & 12.1 & 33.3 & 54.5 & 33 & Pseudoceratina crassa & & 20 & & 80 & 5 \\
\hline Aplysina cauliformis & 13.1 & 3.3 & 36.1 & 47.5 & 122 & Rhaphidophlus isodictyoide & & 40 & 50 & 10 & 10 \\
\hline Aplysina fistularis & 9.7 & & 38.7 & 51.6 & 31 & Rhaphidophlus minutus & & 25 & 37.5 & 37.5 & 8 \\
\hline Artemisina melana & & & 27.3 & 72.7 & 11 & Rhaphidophlus venosus & 0.2 & 22.6 & 33.3 & 43.9 & 424 \\
\hline Axinyssa ambrosia & & 57.1 & 42.9 & & 7 & Scopalina ruetzlen & 0.7 & 12.1 & 33.4 & 53.7 & 1089 \\
\hline Axinyssa flavolivescens & & 14.3 & 71.4 & 14.3 & 7 & Spirastrella coccinea & & 28.6 & 22.9 & 48.6 & 35 \\
\hline Batzella rosea & & & 14.3 & 85.7 & 7 & Terpios belindae & & 19.4 & 46.3 & 34.3 & 67 \\
\hline Batzella sp. & & 71.4 & & 28.6 & 7 & Terpios sp. & & 7 & 29.8 & 63.2 & 57 \\
\hline Callyspongia armigera & 14.3 & & 28.6 & 57.1 & 7 & Topsentia ophiraphiditis & & 15.4 & 23.1 & 61.5 & 13 \\
\hline Callyspongia vaginalis & & & 62.5 & 37.5 & 8 & Verongula rigida & & 22.2 & 27.8 & 50 & 18 \\
\hline Clathria affinis & & 50 & 12.5 & 37.5 & 8 & Xestospongia caminata & & 11.1 & 55.6 & 33.3 & 9 \\
\hline Clathria echinata & & 20 & 40 & 40 & 5 & Xestospongia muta & 5.7 & 34.3 & 28.6 & 31.4 & 35 \\
\hline Clathria sp. 1 & & 22.2 & 61.7 & 30.6 & 36 & Xestospongia proxima & & 11.1 & 55.6 & 33.3 & 9 \\
\hline Clathria sp. 2 & & 10.3 & 41.4 & 48.3 & 29 & & & & & & \\
\hline Clathria sp. 3 & 3.2 & 19.4 & 38.7 & 38.7 & 31 & Coral species & & & & & \\
\hline Clathria spinosa & & 18.8 & 25 & 56.3 & 16 & Acropora palmata & & 14.3 & & 85.7 & 7 \\
\hline Cliona sp. & & & & 100 & 5 & Agaricia agaricites & 4 & 18.3 & 46.2 & 31.5 & 327 \\
\hline Coelosphaera sp. & & 4.1 & 37.8 & 58.1 & 148 & Agaricia lamarckii & & 14.3 & 71.4 & 14.3 & 7 \\
\hline Desmapsamma anchorata & 37.1 & 11.2 & 12.4 & 39.3 & 89 & Colpophyllia natans & & 33.3 & 11.1 & 55.6 & 9 \\
\hline Discoderma dissoluta & & 33.3 & 33.3 & 33.3 & 6 & Dichocoenia stokest & 6.3 & 18.8 & 18.8 & 56.3 & 16 \\
\hline Dragmaxia sp. & & 9.1 & 27.3 & 63.6 & 22 & Diploria labyrinthiformis & & 16.7 & 16.7 & 66.7 & 18 \\
\hline Dysidea etheria & 7.2 & 1.8 & 29.7 & 61.3 & 111 & Diploria strigosa & 1.8 & 14.9 & 25.1 & 58.2 & 275 \\
\hline Eurypon laughlini & & 10.5 & 47.4 & 42.1 & 38 & Helioseris cucullata & & 25 & 50 & 25 & 12 \\
\hline Eurypon sp. & & & 40 & 60 & 5 & Madracis decactis & 3.7 & 22.2 & 43.3 & 30.8 & 487 \\
\hline Forcepia sp. & & 10.3 & 27.6 & 62.1 & 29 & Madracis pharensis & & 6.3 & 56.3 & 37.5 & 16 \\
\hline Halıclona implexiformes & & & 33.3 & 66.7 & 6 & Millepora sp. & 8.2 & 22.4 & 37.3 & 32.1 & 134 \\
\hline Haliclona sp. & & 44.4 & 22.2 & 33.3 & 9 & Montastrea annularis & 2.2 & 38.9 & 17.3 & 41.6 & 185 \\
\hline Halisarca caerulea & & 16.7 & 16.7 & 66.7 & 6 & Montastrea cavernosa & 0.7 & 15.3 & 27.6 & 56.4 & 1604 \\
\hline Iotrochota birotulata & & 14 & 34 & 52 & 50 & Meandrina meandrites & 6 & 4 & 24 & 66 & 50 \\
\hline Ircinia campana & & 20 & & 80 & 5 & Mycetophyllia ferox & & & 11.1 & 88.9 & 9 \\
\hline Ircinia felix & 2.7 & 22.7 & 28.9 & 45.8 & 225 & Porites astreoides & 2.2 & 14.3 & 33.8 & 49.7 & 314 \\
\hline Ircinia strobilina & 4.2 & 31.3 & 6.3 & 58.3 & 48 & Scolymia lacera & 2.6 & 2.6 & 23.1 & 71.8 & 39 \\
\hline Monanchora arbuscula & & 10.3 & 33.3 & 56.4 & 78 & Siderastrea siderea & 10.6 & 15.2 & 35.8 & 38.4 & 151 \\
\hline Mycale diversisigmata & & 16.7 & & 83.3 & 6 & Stephanocoenia michelinii & 3 & 15.8 & 37.9 & 43.3 & 203 \\
\hline
\end{tabular}

$(17.3 \%)$ peripheral contact, $1255(32.5 \%)$ tissue contact and $1845(47.7 \%)$ non contact interactions. In Table 1 the total number of interactions and the frequency of each category of interaction are given for each sponge and coral species. All sponge species except 1 were encountered in non contact interactions ( $n=63$ ). Overgrowth occurred in 16 species, peripheral contact in 52 species and tissue contact in 57 species (see Fig. 5). Because the above-mentioned percentages are derived from the total number of interactions scored, they can be regarded as 'mean' frequencies for each interaction category. To demonstrate differences in these mean frequencies displayed by individual sponge species involved in interactions, the number of sponge species with a certain frequency are shown for each category of interaction (Fig 5). Concerning overgrowth and peripheral contact, most sponge species display frequencies which correspond to the mean frequencies and only a few species show very high or very low frequencies. For tissue contact and non contact interactions, the difference between the number of sponge species with mean frequencies and with higher or lower frequencies is much smaller. Sponges with extremely low or high frequencies of a certain interaction category were mostly those species with only 6 to 8 interactions. Exceptions were the sponges Mycale laevis, with 182 interactions of which $61.5 \%$ consisted of peripheral contact and $10.4 \%$ of non contact interac- 
tions, and Desmapsamma anchorata, with $37.1 \%$ overgrowth out of 89 interactions.

The frequency of peripheral contact, tissue contact and non contact interactions is related to the density of both corals and sponges, as is shown by the positive regression coefficients for sponge and coral cover $(\mathrm{p}<$ 0.001 ; see Table 2). Overgrowth was not related to sponge and coral cover $(\rho>0.05)$. In contrast with the other interaction categories, the frequency of overgrowth seemed to be due to factors other than sponge and coral cover. To determine the relative magnitude of the effects of sponge and coral cover on the number of peripheral contact, tissue contact and non contact interactions, differences between regression coefficients were tested for significance. For tissue and non contact interactions the regression coefficient of sponge cover was significantly higher than the regression coefficient of coral cover (Fig. 6). This means that the frequency of tissue contact and non contact interactions is determined more by sponge than by coral

Table 2. Results of multiple regression analysis of sponge and coral cover on number of interactions. Regression lines were fitted to the linear model: $\log ($ no. of interactions) $=a+$ $b \log$ (sponge cover) + clog(coral cover), where a is a constant and $b$ and $c$ are the slopes of sponge and coral cover, respectively. $R^{2}$ is coefficient of determination; $p$ is probability that rejection of the hypothesis that both slopes are equal to zero is incorrect; $\mathrm{n}$ is number of data points

\begin{tabular}{|lcccccc|}
\hline Dependent variable & $a$ & $b$ & $c$ & $\mathrm{R}^{2}$ & $\mathrm{p}$ & $\mathrm{n}$ \\
\hline Overgrowth & -0.13 & 0.13 & 0.23 & 0.06 & 0.277 & 43 \\
Peripheral growth & -0.18 & 0.55 & 0.75 & 0.58 & $<0.001$ & 45 \\
Tissue contact & 0.64 & 0.60 & 0.28 & 0.56 & $<0.001$ & 44 \\
Non contact & 0.62 & 0.71 & 0.35 & 0.59 & $<0.001$ & 45 \\
\hline
\end{tabular}

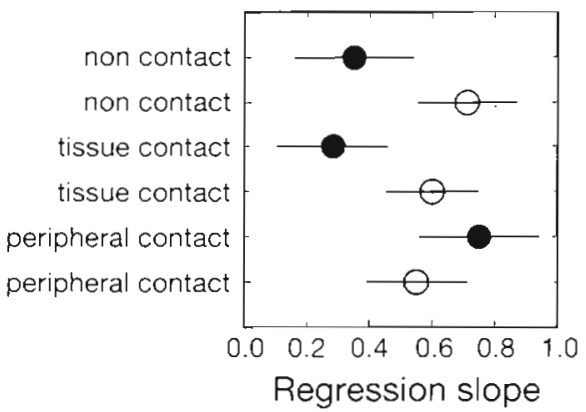

Fig. 6. Regression slopes and 95\% confidence intervals for each category of interaction with sponge cover ( $-\mathrm{O}$ ) and coral cover (- Slopes are significantly different at the 0.05 level if their intervals do not overlap

cover. For the frequency of peripheral contact interactions there is no difference in effect of sponge and coral cover.

\section{Overgrowth by sponges}

The occurrence of overgrowth was tested for similarities between depths and localities to determine its relation with the physical environment. There was a significantly higher frequency of overgrowth at $5 \mathrm{~m}$ compared to $20 \mathrm{~m}(\mathrm{p}<0.05$; Fig. 7A), which corresponds with a higher sedimentation load at $5 \mathrm{~m}$ (Fig 3B). However, no significant difference in overgrowth was found between 5 and $10 \mathrm{~m}$ depths. Also, no significant difference in the frequency of overgrowth could be detected between localities (Fig. 7B), although Punta de Betin is the most stressed locality concerning sedimentation load and visibility (Figs. 3A \& 4).
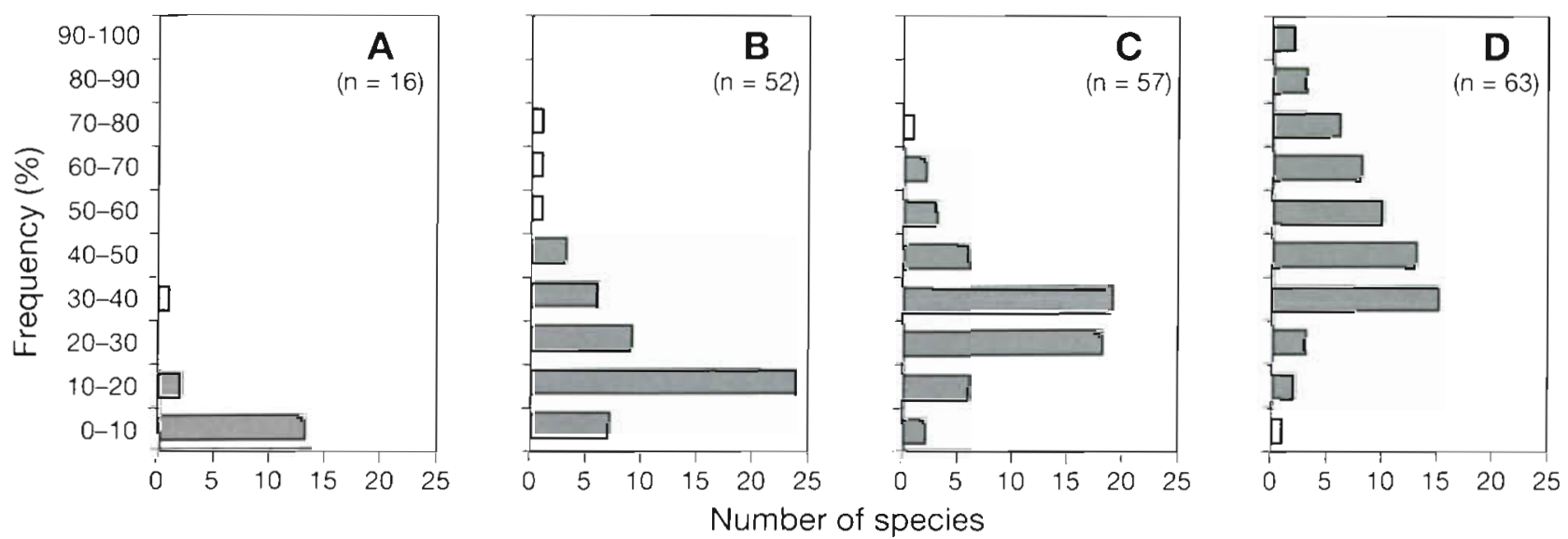

Fig. 5. Frequencies of interaction category displayed by sponge species encountered in interactions. (A) overgrowth; (B) peripheral contact (C) tissue contact; (D) non contact. The number of sponge species involved in each interaction category is shown in parentheses. Frequencies were ordered in classes with increments of $10 \%$. For each category of interaction the vertical axis shows the frequency classes and the horizontal axis the number of sponge species with frequencies within a certain class 


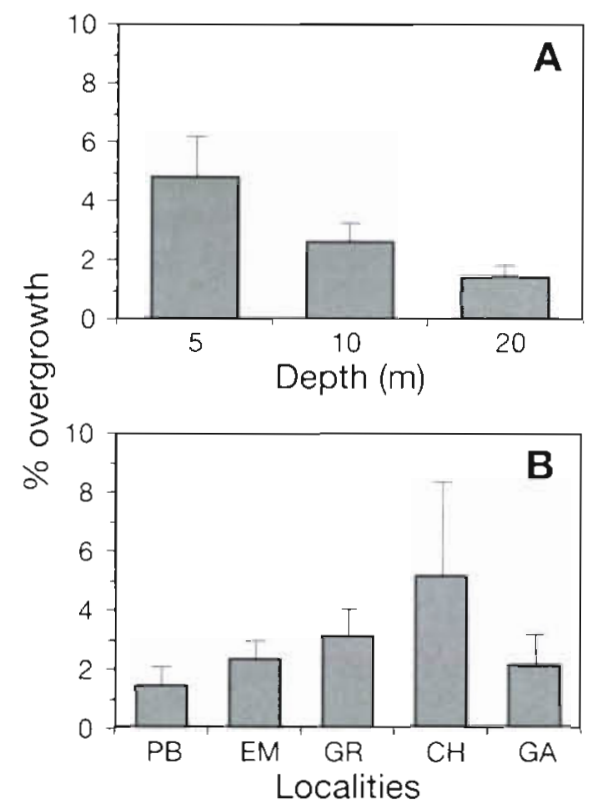

Fig. 7. Percentage overgrowth ( $+\mathrm{SE}$ ) from total number of interactions for $(A)$ depth $(n=5)$ and $(B)$ localities $(n=3)$. Abbrevations of localities as in Fig. 1

Apparently, there is no clear relation between occurrence of overgrowth and physical stress. Since there are some obvious differences in coral overgrowth between sponge species and in coral species overgrown by sponges (Table 1), the sponge and coral species composition may determine the higher frequency of overgrowth at $5 \mathrm{~m}$. The sponges Desmapsamma anchorata, Callyspongia armigera and Aplysina cauliformis for example displayed the most overgrowths and Rhaphidophlus venosus, Mycale laevis and Sco-

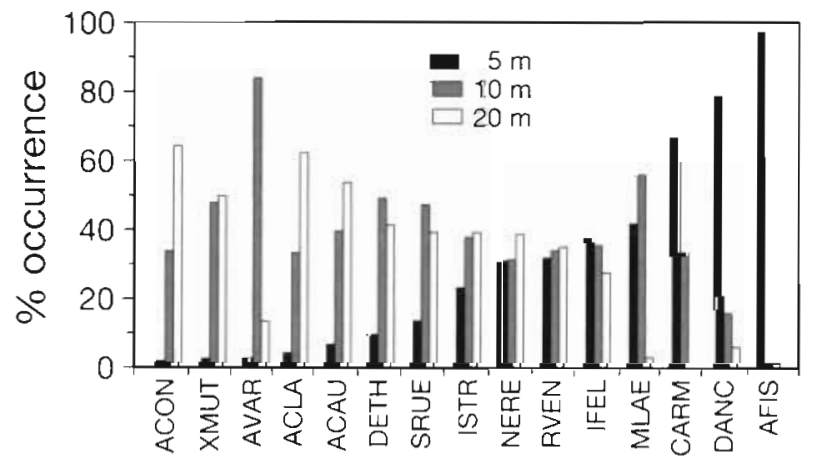

Fig. 8. Percentage occurrence from total number of sponges for each depth and sponge species. ACLA = Agelas clathrodes ACON = Agelas conifera; $\mathrm{ACAU}=$ Aplysina cauliformis; AFIS = Aplysina fistularis; $\mathrm{AVAR}=$ Anthosigmella varians; $\mathrm{CARM}=$ Callyspongia armigera; $\mathrm{DANC}=$ Desmapsamma anchorata DETH $=$ Dysidea etheria $;$ IFEL = Ircinia felix $;$ ISTR = Ircinia strobilina MLAE = Mycale laevis NERE = Niphates erecta; RVEN = Rhaphidophlus venosus; SRUE = Scopalina ruetzleri; and $\mathrm{XMUT}=$ Xestospongia muta palina ruetzleri the least. Corals most affected by sponge overgrowth were the species Siderastrea siderea and the genus Millepora. Least affected were the corals Montastrea cavernosa and Diploria strigosa.

To determine if the frequency of aggressiveness is related to the presence of particular sponge or coral species, the occurrence of sponge individuals and the coral perimeter were compared for species and depth (Figs. 8 \& 9) In Desmapsamma anchorata, the most aggressive sponge species, $78.7 \%$ of all individuals occur at $5 \mathrm{~m}$ depth (Fig. 8). The aggressive sponge species Aplysina fistularis and Callyspongia armigera also reach their highest densities at $5 \mathrm{~m}$ depth, with respectively 97.3 and $66.7 \%$ of all sponge individuals. The coral species most affected by overgrowth of sponges, Siderastrea siderea and Millepora sp., also mainly occur at $5 \mathrm{~m}$ (Fig. 9).

Most sponge species were aggressive towards more than 1 coral species. Susceptibility of corals to overgrowth by sponges varies in a species-specific manner Encounters between particular sponge and coral species depended on the distribution of those sponge and coral species. The frequency of overgrowth was related to the presence of aggressive sponge species, rather than to characteristics of corals.

Until this point we included all sponge species when looking at differences in frequency of overgrowth between localities and depth. However, since frequency of overgrowth depends on the presence of aggressive sponge species, this obfuscates the relation between physical environment and frequency of overgrowth. To determine if overgrowth occurred more frequently in physically stressed localities we focussed on the aggressive sponge species Desmapsamma

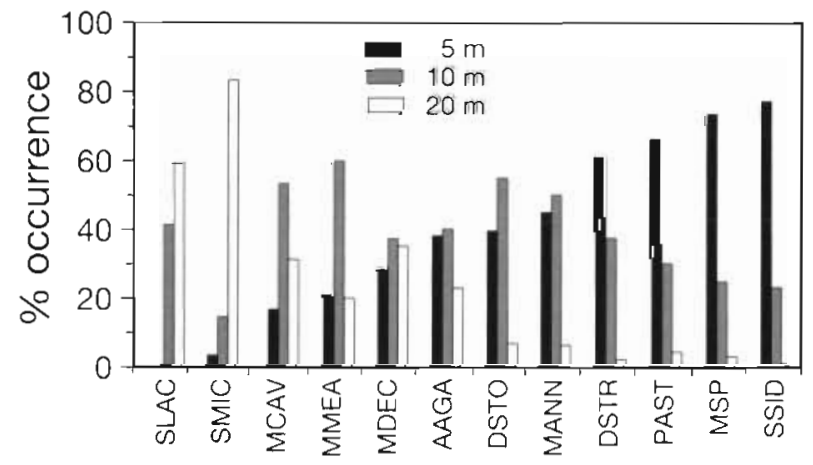

Fig. 9. Percentage occurrence from total perimeter for each depth and coral species. AAGA $=$ Agancia agaricites; $D S T O=$ Dichocoenia stokesi; DSTR = Diploria strigosa; $\mathrm{MDEC}=$ Madracis decactis; $\mathrm{MSP}=$ Millepora sp.; MANN = Montastrea annularis; $\mathrm{MCAV}=$ Montastrea cavernosa; $\mathrm{MMEA}=$ Meandrina meandrites; PAST $=$ Porites astreoides $; \mathrm{SLAC}=$ Scolymia lacera; SSID = Siderastrea siderea, and SMIC = Stephanocoenta michelint 


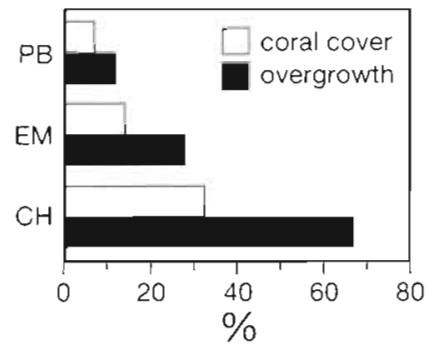

Fig. 10. Frequency of overgrowth (in \%) from total number of interactions of the sponge Desmapsamma anchorata and coral cover (in \%, + SE) for the localities Punta de Betin (PB, most stressed), El Morro (EM, intermediately stressed) and Chengue $(\mathrm{CH}$, least stressed) at $5 \mathrm{~m}$ depth. At Granate this sponge was not recorded and at Gairaca there was only 1 interaction

anchorata. Coral. overgrowth by this species and mean coral cover at $5 \mathrm{~m}$ depth are shown for the localities PB (highest sedimentation and low visibility; most stressed locality), $\mathrm{CH}$ (low sedimentation and high visibility; least stressed) and EM (low sedimentation, low visibility; intermediately stressed). Coral cover was significantly highest at $\mathrm{CH}$ and lowest at $\mathrm{PB}$, but overgrowth occurred more often in $\mathrm{CH}$ (Fig. 10). Apparently the frequency of overgrowth is not related to stress. On the contrary, the sponge D. anchorata was more frequently engaged in aggressive encounters in localities with relatively less stress and high coral cover.

\section{DISCUSSION}

\section{Nature of sponge/coral interactions}

Sponges are reported to be competitively dominant over corals (Jackson \& Buss 1975, Vicente 1978, Suchanek et al. 1983, Sullivan et al. 1983, Porter \& Targett 1988, Rützler \& Muzik 1993). However, the first study quantifying sponge/coral interactions on a community level (our study) shows only $2.5 \%$ of all sponge/coral encounters to be directly aggressive, i.e. overgrowth of corals by sponges. Sponge/coral interactions occurring most frequently were, in decreasing order of occurence, (1) non contact, (2) tissue contact, (3) peripheral contact. The degree and quality of interaction in these encounters is unknown. Some sponges exude toxic substances in their direct vicinity (Thompson 1985) and affect corals by direct or indirect contact (Porter \& Targett 1988), but other species release no waterborne allelopathic substances (Bingham \& Young 1991). Corals can damage neighboring organisms using mesenterial filaments and sweeper tentacles (Lang \& Chornesky 1990). In coral-alga interactions damage and growth inhibition of algal thallae were observed at the periphery of, or at short distance from, a coral (De Ruyter van Steveninck et al. 1988). If the neighboring organism is a sponge competing by means of toxic chemicals, inflicting damage could have a reverse effect because damaged sponges release increased levels of secondary metabolites (Thompson 1985). In our study no visible negative effects on sponges or corals were observed in peripheral, tissue or non contact interactions. The actual competitive event of sponge/coral interaction may result in an equilibrium through growth inhibition of both organisms (Karlson 1980).

The growth forms of partners in interaction is important in spatial competition (Lang 1973) and can determine the frequency of specific categories of interactions. Massive sponge species, displayed more peripheral contact than branched species, as is shown by the massive species Ircinia strobilina and the branched species Aplysina cauliformis, with respectively 31.3 and $3.3 \%$ of peripheral contact. Supposedly, encrusting and massive species will be more effective than branching species in gaining space by means of overgrowth, because branching species can avoid competition by 'escaping in height' (Meesters et al 1996). However, growth form is not the most important feature in determining the frequency of overgrowth. The sponge species Desmapsamma anchorata and $A$. cauliformis were the 2 most aggressive species, despite their ability to 'escape in height'. The ability to overgrow corals may depend on the possession of specific characteristics which vary between species. The possession of toxic secondary metabolites is considered to be a favourable feature in competition for space, but possession of toxic substances does not automatically imply use in competition for space. The toxic activity can be very specific, as is shown in various bioassay studies (Bakus et al. 1990, Green et al. 1990). The aggressive sponge species $A$. cauliformis is known to possess toxic chemicals demonstrating antiviral activity (Gunasekera et al. 1991). The sponge D. anchorata also possesses unusual organic molecules, e.g. alkylglycerol monoethers (Quijano et al. 1994), and it was the sponge species most aggressive towards corals. Whether $D$. anchorata, A. cauliformis or other sponge species use their secondary metabolites in competition for space with corals still remains to be demonstrated.

\section{Overgrowth and physical stress}

Competitive dominance of sponges as a group over corals as a group is not shown by our results, and it appears impossible to generalize about effectiveness 
of sponges in killing corals or about susceptibility of corals to sponge aggression. The frequency of overgrowth of corals by sponges was found to depend on the presence of particular sponge species. Only 16 of the 95 sponge species were engaged in aggressive interactions and these 16 sponge species were not equally aggressive in terms of overgrowth. Since the mechanisms of competition for space differ between individual sponge and coral species, and because a number of ather factors may influence the outcome of these interactions, sponge/coral interactions likely form complex networks. When space is limited and disturbance low (e.g. in cryptic habitats; Jackson \& Buss 1975, Buss \& Jackson 1979), overgrowth capability will be selectively favoured and aggressive sponge species will be able to out-compete corals. That overgrowth was rather rare compared to the other categories of interactions may be indicative of its minor importance as a competitive strategy in the physically stressed coral reef communities of Santa Marta. External disturbances can alter existing competitive hierarchies or networks by reducing the competitive ability of some species more than that of others (Connell 1976).

The hypothesis that physical stress reduces the competitive ability of corals more than that of sponges, leading to a relative increase of overgrowth of corals by sponges (e.g. Rützler \& Muzik 1993), is not confirmed by our results. Environmental stress did not lead to an increase in overgrowth of corals by sponges. No significant differences in the frequency of overgrowth were found among our 5 localities, although Punta de Betin was most stressed in terms of sedimentation load and light conditions. Focussing on the aggressive sponge species Desmapsamma anchorata, it appears that overgrowth is related to coral cover rather than to physical stress. We reject the hypothesis that the frequency of aggressive sponge/coral interactions is related to physical stress for corals. Sponges do not necessarily overgrow corals when they are confronted with them; only when coral cover is high and available space limited is coral overgrowth more often encountered.

In conclusion, physical stress does not necessarily lead to an increase in overgrowth of corals by sponges. Overgrowth was related to the degree of aggressiveness of sponge species, rather than to characteristics of corals. Reef sponges differ notably in their ability to overgrow corals as is shown by differences in overgrowth frequencies. Sponge species abundance varies among depths, probably as a result of different requirements concerning physical conditions. Thus, by influencing the sponge community composition on the reef, the physical environment may indirectly determine the extent of overgrowth of corals by sponges.
Acknowledgements. We are grateful to Mr P. A. J. van der Wolf for his help with practical problems and to Dr S. Zea for his help in identifying some sponge species and for his comments on our manuscript. Dr L. Botero is thanked for the facilities offered by the INVEMAR, and boatsman J. Gonzalez for his support on the field trips. We thank Prof. Dr R. P. M. Bak for his suggestions and constructive critisism with regard to the manuscript, Dr M. J. de Kluijver for the discussions on sponge/coral interactions, and Msc. M. Kielman for making available to us her data on sedimentation rates of the coral reef communities of Santa Marta. The manuscript has been improved considerably due to the comments of 3 anonymous reviewers. This research was made possible by a grant from the Netherlands Organization for Scientific Research in the tropics (WOTRO, project no. W84-342).

\section{LITERATURE CITED}

Bak RPM, Termaat RM, Dekker R (1982) Complexity of coral interactions: influence of time, locality of interaction and epifauna. Mar Biol 69:215-222

Bakus GJ, Schulte B, Jhu S, Wright M, Green G, Gomez P (1990) Antibiosis and antifouling in marine sponges: laboratory versus field studies. In: Rützler K (ed) New perspectives in sponge biology. Smithsonian Inst Press, Washington, DC, p 102-108

Bingham BL, Young CM (1991) Influence of sponges on invertebrate recruitment: a field test of allelopathy. Mar Biol 109:19-26

Bradbury RH, Young PC (1983) Coral interactions and community structure: an analysis of spatial pattern. Mar Ecol Prog Ser 11:265-271

Buss LW, Jackson JBC (1979) Competitive networks: nontransitive competitive relationships in cryptic coral reef environments. Am Nat 113:223-234

Chalker BE, Carr K, Gill E (1985) Measurement of primary production and calcification in situ on coral reefs using electrode techniques. Proc 5 th lnt Coral Reefs Congr. Tahiti 6:167-172

Chornesky EA (1989) Repeated reversals during spatial competition between corals. Ecology 70(4):843-855

Connell JH (1976) Competitive interactions and the species diversity of corals. In: Mackie GO (ed) Coelenterate ecology and behaviour. Plenum Press, New York, p 51-58

Cruz E, Ramirez G (1990) Caracterizacion quimica de las aguas residuales del municipio de Santa Marta, costa Caribe Colombiana. Contam Ambiental 22:27-34

Dayton PK (1971) Competition, disturbance and community organization: the provision and subsequent utilization of space in a rocky intertidal community. Ecol Monogr 41. $351-389$

De Ruyter van Steveninck ED, Van Mulekom LL, Breeman AM (1988) Growth inhibition of Lobophora variegata (Lamouroux) Wormersley by scleractinian corals. J Exp Mar Biol Ecol 115:169-178

Escobar NA (1988) Estudio de algunas aspectos ecologicos y de la contaminacion bacteriana en la Bahia de Santa Marta. An Inst Invest Mar Punta Betin 18:39-57

Green G, Gomez P, Bakus GJ (1990) Antimicrobial and ichthyotoxic properties of marine sponges from Mexican waters. In: Rützler K (ed) New perspectives in sponge biology. Smithsonian Inst Press, Washington, DC, p 109-114

Gunasekera SP, Cross SS, Longley RE, Pomponi SA (1991) The chemistry and the biological activity of five marine sponges of the genus Aplysina. In: Pezzuto JM, Kinghorn AD, Fong HHS, Cordell GA (eds) Progress on terrestrial and marine 
natural products of medicinal and biological interest. Un1versity of Illmois, Chicago, 1991:53-58

Jackson JBC (1977) Competition on marine hard substrata: the adaptive significance of solitary and colonial strategies. Am Nat 111:743-767

Jackson JBC, Buss LW (1975) Allelopathy and spatial competition among coral reef invertebrates. Proc Nat Acad Sci USA 72:5160-5163

Karlson RH (1980) Alternative competitive strategies in a perıdically disturbed habitat. Bull Mar Sci 30:894-900

Lang JC (1971) Interspecific aggression by scleractinian corals. 1. The rediscovery of Scolymia cubensis (Milne Edwards \& Haime). Bull Mar Sci 21:952-959

Lang JC (1973) Interspecific aggression by scleractinian corals. 2 . Why the race is not only to the swift. Bull Mar Sci $23: 260-279$

Lang JC, Chornesky EA (1990) Competition between scleractinian reef corals - a review of mechanisms and effects. In: Dubinsky $Z$ (ed) Coral reefs: ecosystems of the world, Vol 25. Elsevier, Amsterdam, p 209-252

Larsson U, Blomqvist S, Abrahamsson B (1986) A new sediment trap system. Mar Ecol Prog Ser 31:205-207

Logan A (1984) Interspecific aggression in hermatypic corals from Bermuda. Coral Reefs 3:131-138

Meesters EH, Bak RPM (1993) Effects of coral bleaching on tissue regeneration potential and colony survival. Mar Ecol Prog Ser 96:189-198

Meesters EH, Wesseling I, Bak RPM (1996) Partıal mortalıty in three species of reef-building corals and the relation with colony morphology. Bull Mar Sci 58:838-852

Pastorok RA, Bilyard GR (1985) Effects of sewage pollution on coral-reef communities. Mar Ecol Prog Ser 21:175-189

Porter JW (1987) Species profiles: life histories and environmental requirements of coastal fishes and invertebrates (South Florida). Reef building corals. US Fish Wildl Serv Biol Rep 82:1-23

Porter JW, Targett NM (1988) Allelochemical interactions between sponges and corals. Biol Bull 175:230-239

Quijano L, Cruz F, Navarette J, Gomez P, Rios T (1994) Alkylglycerol monoethers in the marine sponge Desmapsamma anchorata. Lipids 29:731-734

Richardson CA, Dustan P, Lang JC (1979) Maintenance of living space by sweeper tentacles of Montastrea cavernosa, a Caribbean reef coral. Mar Biol 55:181-186

This article was submitted to the editor
Rinkevich B, Loya $Y(1985)$ Intraspecific competition in a reef coral: effects on growth and reproduction. Oecologia (Berlin) 66:100-105

Rogers CS (1990) responses of coral reefs and organisms to sedimentation. Mar Ecol Prog Ser 62: 185-202

Russ GR (1.982) Overgrowth in a marine epifaunal community: competitive hierarchies and competitive networks Oecologia (Berlin) 53:12-19

Rützler K, Muzik K (1993) Terpios hoshinota, a new cyanobacteriosponge threatening Pacific reefs. Sci Mar 57 $395-403$

Sokal RR, Rohlf FJ (1981) Biometry. WH Freeman \& Co, New York

Suchanek TH, Carpenter RC, Witman JD, Harvell CD (1983) Sponges as mportant space competitors in deep Caribbean coral reef communities. In: Reaka ML (ed) The ecology of deep and shallow coral reefs. Symposia series for undersea research 1. NOAA/NURP, Rockville, MD, p 55-60

Sullivan B, Faulkner DJ, Webb L (1983) Siphonodictine, a metabolite of the burrowing sponge Siphonodictyon sp. that inhibits coral growth. Science 221:1175-1176

Thompson JE (1985) Exudation of biologically-active metabolites in the sponge Aplysina fistularis. I. Biological evidence. Mar Biol 88:23-26

Vicente VP (1978) An ecological evaluation of the West Indian Demosponge Anthosigmella varians (Hadromerida: Spirastrellidael. Bull Mar Sci 28:771-777

Von Prahl H, Erhardt H (1985) Colombia, corales y arrecifes coralinos. FEN Colombia, Bogota

Werding B, Sanchez. H (1988) Deterioro observado en las formaciones coralinas de la Bah'a de Santa Marta, Colombia. An Inst Invest Mar Punta de Betin 18:9-16

Wilkinson CR, Cheshire AC (1990) Comparisons of sponge populations across the Barrier Reefs of Australia and Belize: evidence for higher productivity in the Caribbean. Mar Ecol Prog Ser 67:285-294

Zea $S$ (1994) Patterns of coral and sponge abundance in stressed coral reefs at Santa Marta, Colombian Caribbean. In: van Soest RWM, van Kempen ThMG, Braekman JC (eds) Sponges in time and space. Balkema, Rotterdam, p $257-264$

Zea S, Duque C (1989) Bleaching of reef organisms in the Santa Marta region, Colombia: 1987 Caribbean-wide event. Trianea (Act Cient Tecnol INDERENA) 3:37-51

Manuscript first received: March 8, 1996

Revised version accepted: December 30, 1996 